\title{
Biocatalytic Synthesis and Polymerization via ROMP of New Biobased Phenolic Monomers: A Greener Process toward Sustainable Antioxidant Polymers
}

\author{
Florian Diot-Néant ${ }^{1,2+}$, Loïs Migeot ${ }^{1+}$, Louis Hollande ${ }^{1,3}$, Felix A. Reano ${ }^{1,3}$, \\ Sandra Domenek ${ }^{3}$ and Florent Allais ${ }^{1,4 *}$
}

OPEN ACCESS

Edited by:

Alexei Lapkin

University of Cambridge,

United Kingdom

Reviewed by:

Gabit Nurumbetov,

Medherant Ltd, United Kingdom

Victor Sans Sangorrin,

University of Nottingham,

United Kingdom

Werner Pauer,

University of Hamburg, Germany

Claudia Sayer,

Universidade Federal de Santa

Catarina, Brazil

*Correspondence:

Florent Allais

florent.allais@agroparistech.fr

${ }^{\dagger}$ These authors have contributed equally to this work.

Specialty section:

This article was submitted to Chemical Engineering,

a section of the journal

Frontiers in Chemistry

Received: 02 October 2017 Accepted: 12 December 2017 Published: 22 December 2017

Citation:

Diot-Néant F, Migeot L, Hollande L, Reano FA, Domenek $S$ and Allais $F$ (2017) Biocatalytic Synthesis and Polymerization via ROMP of New

Biobased Phenolic Monomers: A Greener Process toward Sustainable Antioxidant Polymers.

Front. Chem. 5:126.

doi: 10.3389/fchem.2017.00126
${ }^{1}$ Chaire ABI, AgroParisTech, CEBB, Pomacle, France, ${ }^{2}$ The George and Josephine Butler Laboratory for Polymer Research, Department of Chemistry, University of Florida, Gainesville, FL, United States, ${ }^{3}$ UMR GENIAL, AgroParisTech, Institut National De la Recherche Agronomique, Université Paris-Saclay, Massy, France, ${ }^{4}$ UMR 782 GMPA, AgroParisTech, Institut National de la Recherche Agronomique, Université Paris-Saclay, Thiverval-Grignon, France

Antioxidant norbornene-based monomers bearing biobased sterically hindered phenols (SHP)-NDF (norbornene dihydroferulate) and NDS (norbornene dihydrosinapate) - have been successfully prepared through biocatalysis from naturally occurring ferulic and sinapic acids, respectively, in presence of Candida antarctica Lipase $B$ (Cal-B). The ring opening metathesis polymerization (ROMP) of these monomers was investigated according to ruthenium catalyst type (GI) vs. (HGII) and monomer to catalyst molar ratio $([\mathrm{M}] /[\mathrm{C}])$. The co-polymerization of antioxidant functionalized monomer (NDF or NDS) and non-active norbornene (N) has also been performed in order to adjust the number of SHP groups present per weight unit and tune the antioxidant activity of the copolymers. The polydispersity of the resulting copolymers was readily improved by a simple acetone wash to provide antioxidant polymers with well-defined structures. After hydrogenation with $p$-toluenesulfonylhydrazine ( $p$-TSH), the radical scavenging ability of the resulting saturated polymers was evaluated using $\alpha, \alpha$-diphenyl- $\beta$-picrylhydrazyl (DPPH) analysis. Results demonstrated that polymers bearing sinapic acid SHP exhibited higher antiradical activity than the polymer bearing ferulic acid SHP. In addition it was also shown that only a small SHP content was needed in the copolymers to exhibit a potent antioxidant activity.

Keywords: antioxidants, ROMP, lipase, CAL-B, norbornene, ferulic acid, sinapic acid, DPPH

\section{INTRODUCTION}

The fundamental principle for the stabilization of polymeric materials consists in preserving the initial aesthetic and mechanical properties of a polymer during processing, storage, and application. In fact, polymeric materials are commonly exposed to several external effects, such as heat, oxygen, radiation, residual metal catalyst, and mechanical stress which are well-known to promote undesirable deterioration of theses mechanical, physical and of course chemicals properties (Pospísill, 1993; Zweifel, 1998). The addition of antioxidants in small amounts to polymers is a convenient and efficient way to drastically delay their deterioration. Many classes 
of antioxidant additives, often used in combination to achieve synergy, are commercialized and classified according to their mechanisms of action. Sterically hindered phenols (SHP) such as Irganox ${ }^{\circledR}$ 1010, $\operatorname{Irganox}^{\circledR}$ 1076, BHT, or Ethanox ${ }^{\circledR}$ 330, are by far the most commonly used class used in industry (Girois, 2013). These antioxidants belong to the group of free radical-scavengers and act like radical inhibitors $(\mathrm{IH})$ based on the transfer of a hydrogen atom from the $\mathrm{IH}$ to the free radical species $\mathrm{R}^{\bullet}$ or an oxidative associated product and results in less reactive products $\mathrm{RH}$ and $\mathrm{I}^{\bullet}$.

Unfortunately, conventional antioxidants are not perfect and suffer from some serious limitations. Because of low molecular weight, antioxidants are easily subject to depart from the polymer matrix by physical loss such as migration, evaporation, leaching and extraction (Marcato et al., 2003; Dopico-García et al., 2007). This is a serious issue because food contamination by antioxidants or potentially by-products can negatively impact human health. In addition, the physical loss decreases the effective protective capabilities of antioxidant. Therefore, additives that are potentially able to migrate into food or ending up in environmental medium are strictly controlled by safety-regulations through composition limits in the plastic or migration limits (Code of Federal Regulations Title 21, 2013).

The most common strategy used to limit the physical loss of stabilizers is increasing their molecular weight to minimize their mobility (Kasza et al., 2015). Two general methods to synthesize these larger antioxidant polymers have been reported: chemical modification of pre-formed polymers, or polymerization of antioxidant monomers. The first approach involves the post-functionalization of reactive groups of natural (Arefjev et al., 1999; Sousa et al., 2009) or synthetic (Kim and Oh, 2004) polymer chains with sterically hindered phenol groups (SHP) with the aim to improve their antioxidant activity. This method is quite efficient and easily accessible, but may trigger undesirable side reactions, especially regarding the difficulty to obtain full distribution of stabilizers at the reactive sites of the matrix. In addition, part of SHP groups is consumed or subject to homopolymerization during grafting reactions, rending difficult the preparation of polymers with a controllable structure. The second approach consists in the oligomerization of antioxidant-functionalized monomers. In this case, the monomer design is the key point for adjusting final performances of functionalized polymers. Moreover, depending on the type of polymerization and catalyst used, this approach provides more control and flexibility of the resulting structure of the antioxidant polymers. Many elegant and efficient methods have been developed to design antioxidant monomers (e.g., vinyl, acryl, styrenic) which can be useful in conventional polymerization techniques (Xue et al., 2007). Unfortunately, the major drawbacks of these reactions are the highly carcinogenic by-products formed or the often-hazardous reagents used in these synthetic pathways (e.g., dichloromethyl (Campbell et al., 2001), or alkenylchloride).

ROMP is an attractive and versatile tool for preparing functional and linear polymers or copolymers. Grubbs et al. reported a family of well-defined ruthenium catalysts for

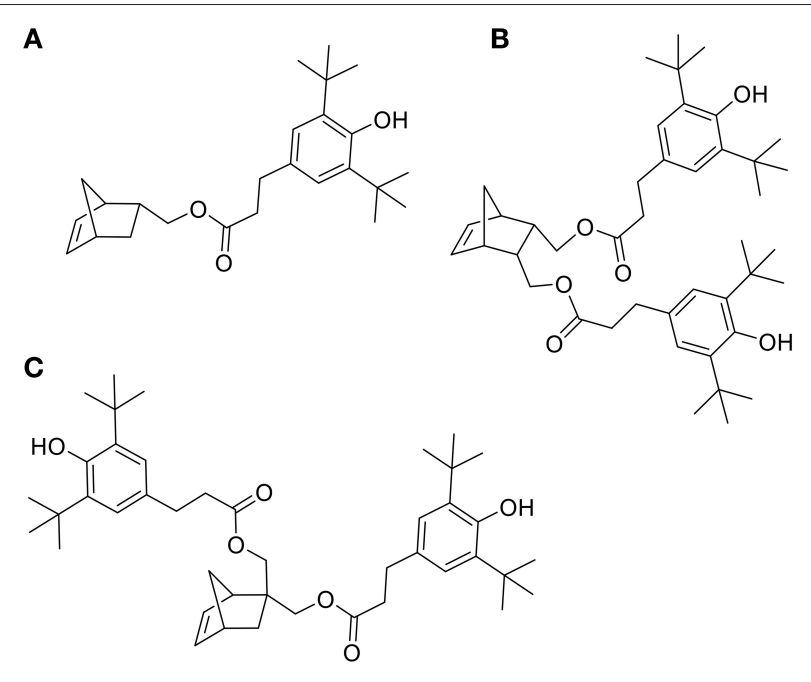

FIGURE 1 | Monomers (A-C) used in ROMP by Xue.

ROMP (Schwab et al., 1996). Although ruthenium catalysts show activities much lower that of the early transition metals catalysts, they provide a clearly better balance between activity and significant tolerance toward functional groups (Nguyen and Grubbs, 1993; Dias et al., 1997; Scherman et al., 2002). Xue and coworkers reported on the synthesis and ROMP of a family of norbornene monomers bearing one or two phenolic antioxidant moieties (Figures 1A-C). However, these compounds and their synthetic procedure have major drawbacks, indeed not only the SHP used 3,5-di-tert-butyl-4-hydroxylphenoxyacetyl chloride - is fossilbased but the synthetic process also involves the use of pyridine, a recognized toxic chemical (Xue et al., 2007, 2008).

In the present work, we report a new and greener pathway to biobased antioxidant phenolic polymers through the chemoenzymatic synthesis of new hindered phenol-functionalized norbornene derivatives from naturally occurring ferulic and sinapic acids using Candida antarctica Lipase B (Cal-B) and their homo/copolymerization using ROMP. Ferulic acid, naturally present at relatively high concentrations in the cell walls of several plants, is known for acting as a free radical scavenger due to its hydrogen donating ability. Many researchers have engaged in high scale production of this acid using techniques like extraction from agricultural wastes (Tilay et al., 2008), enzymatic fractionation (Dupoiron et al., 2017) or more recently by fermentation (Overhage et al., 2003). Ferulic acid can also be synthesized from vanillin using a Knovenagel condensation with malonic acid. Sinapic acid, offers an extra methoxy group at the ortho-position (electron donor) that further increases the antioxidant activity (Cuvelier et al., 1992). Similarly to ferulic acid, sinapic acid can be extracted directly from biomasses such as canola cake or mustard bran but can also be easily obtained from syringaldehyde by condensation with malonic acid as previously reported (Jaufurally et al., 2016). 


\section{EXPERIMENTAL}

\section{Materials}

Syringaldehyde, malonic acid, ferulic acid, $\mathrm{Pd} / \mathrm{C}$, norborneneendo-2,3-dicarboxylic anhydride and lithium aluminum hydride were purchased from Sigma-Aldrich. Candida antarctica Lipase B was purchased from Novozyme. Solvents were purchased from ThermoFisher Scientific and VWR. Deuterated chloroform $\left(\mathrm{CDCl}_{3}\right)$ and acetone $\left(\left(\mathrm{CD}_{3}\right)_{2} \mathrm{CO}\right)$ were purchased from Eurisotop. Column chromatographies were carried out with an automated flash chromatography (PuriFlash 4100, Interchim) and pre-packed INTERCHIM PF-30SI-HP (30 $\mu \mathrm{m}$ silica gel) columns using a gradient of cyclohexane and ethyl acetate for the elution. NMR analyses were recorded on a Bruker Fourier 300 (Supplementary Data Sheet 1). ${ }^{1} \mathrm{H}$ NMR spectra of samples were recorded in $\mathrm{CDCl}_{3}$ at $300 \mathrm{MHz}$, chemical shifts were reported in parts per million $\left(\mathrm{CDCl}_{3}, \mathrm{CHCl}_{3}\right.$ residual signal at $\delta=7.26 \mathrm{ppm}$; Acetone- $\mathrm{d}_{6}$, acetone residual signal at $\left.\delta=2.05 \mathrm{ppm}\right) .{ }^{13} \mathrm{C} \mathrm{NMR}$ spectra of samples were recorded at $75 \mathrm{MHz}\left(\mathrm{CDCl}_{3}\right.$ signal at $\delta$ $=77.16 \mathrm{ppm}$; Acetone residual signal at $\delta=29.84$ and 206.26 ppm). HRMS were recorded by the PLANET platform at URCA on a Micromass GC-TOF.

Thermo-gravimetric analyses (TGA) were recorded on a Q500, from TA. About $10 \mathrm{mg}$ of each sample was heated at $10{ }^{\circ} \mathrm{C} \cdot \mathrm{min}^{-1}$ from 30 to $500{ }^{\circ} \mathrm{C}$ under nitrogen flow $\left(60 \mathrm{~mL} \cdot \mathrm{min}^{-1}\right)$. Differential scanning calorimetry (DSC) thermograms were obtained using a DSC Q20 and Tzero Hermetic Lid pans from TA, under inert atmosphere $\left(\mathrm{N}_{2}\right)$, with a calibration using indium, $n$-octadecane and $n$-octane standards. For each sample, about $10 \mathrm{mg}$ were weighed in a pan which was then sealed and submitted to 3 heat/cool/heat cycles: heating from $30{ }^{\circ} \mathrm{C}$ to $200{ }^{\circ} \mathrm{C}$ at $10^{\circ} \mathrm{C} \cdot \mathrm{min}^{-1}$, cooling from $200{ }^{\circ} \mathrm{C}$ to $-50^{\circ} \mathrm{C}$ at $20^{\circ} \mathrm{C} \cdot \mathrm{min}^{-1}$. Glass transition temperatures $(\mathrm{Tg})$ were determined at the inflexion value in the heat capacity jump.

Gel permeation chromatography (GPC) analyses were performed on an Agilent Infinity 1,260 equipped with four detectors (UV, $\lambda=280 \mathrm{~nm}$, RI, LS, viscosimeter). About $3 \mathrm{mg}$ of polymer of each sample was dissolved in $1 \mathrm{~mL}$ THF (stabilize with BHT). The column PL Gel MIXED-D $(5 \mu \mathrm{m}, 300 \times$ $7.5 \mathrm{~mm}$ ) was calibrated with polystyrene standards in THF flow $\left(1 \mathrm{~mL} \cdot \mathrm{min}^{-1}\right)$.

\section{Monomer Synthesis}

\section{Synthesis of Norbornene Dihydroferulate (NDF)}

In a round-bottom flask, cis-5-norbornene-2,3-endo-dimethanol $(10.04 \mathrm{~g}, 69.22 \mathrm{mmol})$ are charged with ethyl (dihydro)ferulate (46.52 g, $207.66 \mathrm{mmol}, 3$ equiv) and CAL-B (Candida antarctica Lipase B, $5.66 \mathrm{~g}, 10 \%(\mathrm{w} / \mathrm{w}))$. The mixture is heated at $75{ }^{\circ} \mathrm{C}$ under reduced pressure. After 3 days of reaction, the medium is solubilized in $250 \mathrm{~mL}$ of AcOEt and the supported enzyme is eliminated by filtration. After concentration, a yellow oil is obtained and purified by flash purification on silica gel (cyclohexane/AcOEt: 85/15, then 55/45) to provide a colorless oil (30.7 g, 87\%). ${ }^{1} \mathbf{H}$ NMR $\left(\mathrm{CDCl}_{3}, 300 \mathrm{MHz}, \boldsymbol{\delta}\right):$ 6.83-6.66 (m, 6H, $\left.\mathrm{H}_{5,8,9}\right), 6.10$ (t, $\left.2 \mathrm{H}, J=1.8 \mathrm{~Hz}, \mathrm{H}_{1^{\prime}}\right), 5.50\left(\mathrm{~s}, 2 \mathrm{H}, \mathrm{H}_{11}\right), 3.86$ (s, $6 \mathrm{H}$, $\left.\mathrm{H}_{10}\right), 3.83-3.69\left(\mathrm{~m}, 4 \mathrm{H}, \mathrm{H}_{5^{\prime}}\right), 2.87\left(\mathrm{t}, 4 \mathrm{H}, J=8.1 \mathrm{~Hz}, \mathrm{H}_{2}\right), 2.81$ $\left(\mathrm{m}, 2 \mathrm{H}, \mathrm{H}_{2^{\prime}}\right), 2.59\left(\mathrm{t}, 2 \mathrm{H}, J=7.2 \mathrm{~Hz}, \mathrm{H}_{3}\right), 2.46\left(\mathrm{~m}, 2 \mathrm{H}, \mathrm{H}_{4^{\prime}}\right), 1.47$ (app.dd, $1 \mathrm{H}, J=8.4 \mathrm{~Hz}, \mathrm{H}_{3^{\prime}}$ ), 1.27 (app.dd, $1 \mathrm{H}, J=8.4 \mathrm{~Hz}, \mathrm{H}_{3^{\prime}}$ ). ${ }^{13} \mathrm{C}$ NMR ( $\mathrm{CDCl}_{3}, 75 \mathrm{MHz}$, 8): $172.9\left(\mathrm{C}_{1}\right), 146.5\left(\mathrm{C}_{6}\right), 144.2$ $\left(\mathrm{C}_{7}\right), 135.5\left(\mathrm{C}_{1^{\prime}}\right), 132.5\left(\mathrm{C}_{4}\right), 120.9\left(\mathrm{C}_{5}\right), 114.4\left(\mathrm{C}_{8}\right), 111.1\left(\mathrm{C}_{6}\right)$, $64.6\left(\mathrm{C}_{5^{\prime}}\right), 56.0\left(\mathrm{C}_{10}\right), 49.1\left(\mathrm{C}_{3^{\prime}}\right), 45.6\left(\mathrm{C}_{2^{\prime}}\right), 40.7\left(\mathrm{C}_{4^{\prime}}\right), 36.4\left(\mathrm{C}_{2}\right)$, $30.9\left(\mathrm{C}_{3}\right)$. FT-IR (neat): $\nu_{\max } 3443(\mathrm{ArOH}), 1723(\mathrm{C}=\mathrm{O}), 1603-$ $1450\left(\mathrm{C}=\mathrm{C}_{\text {Ar }}\right)$. UV (nm): $\lambda_{\max }: 215$. HRMS (TOF MS, ES+): $m / z$ calcd for $\mathrm{C}_{29} \mathrm{H}_{34} \mathrm{O}_{8} \mathrm{Na}$ : 533.2151; found: 533.2161

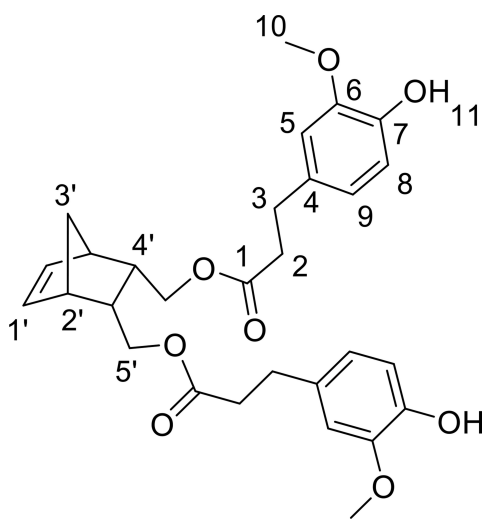

\section{Synthesis of Norbornene Dihydrosinapate (NDS)}

In a round-bottom flask, cis-5-norbornene-2,3-endo-dimethanol $(2.01 \mathrm{~g}, 13.03 \mathrm{mmol})$ are charged with of ethyl (dihydro)sinapate (9.89 g, $39.1 \mathrm{mmol}, 3$ equiv) and CAL-B (Candida antarctica Lipase B, $1.19 \mathrm{~g}(10 \% \mathrm{w} / \mathrm{w}))$. The mixture is heated at $75{ }^{\circ} \mathrm{C}$ under reduced pressure. After 12 days of reaction, the medium is solubilized in $100 \mathrm{~mL}$ of AcOEt and the supported enzyme is eliminated by filtration. After concentration, a yellow oil is obtained and purified by flash purification on silica gel (cyclohexane/AcOEt: 85/15, then 55/45) to provide a colorless oil (4.462 g, 60\%). ${ }^{\mathbf{1}} \mathbf{H}$ NMR ( $\left.\mathrm{CDCl}_{3}, 300 \mathrm{MHz}, \delta\right): 6.43$ (s, 4H, H ), $6.11\left(\mathrm{t}, 2 \mathrm{H}, J=1.8 \mathrm{~Hz}, \mathrm{H}_{1^{\prime}}\right), 5.39\left(\mathrm{~s}, 2 \mathrm{H}, \mathrm{H}_{9}\right), 3.87\left(\mathrm{~s}, 12 \mathrm{H}, \mathrm{H}_{8}\right)$, $3.82-3.70\left(\mathrm{~m}, 4 \mathrm{H}, \mathrm{H}_{5^{\prime}}\right), 2.88\left(\mathrm{t}, 4 \mathrm{H}, J=8.1 \mathrm{~Hz}, \mathrm{H}_{2}\right), 2.83(\mathrm{~m}, 2 \mathrm{H}$, $\left.\mathrm{H}_{2^{\prime}}\right), 2.61\left(\mathrm{t}, 4 \mathrm{H}, J=7.2 \mathrm{~Hz}, \mathrm{H}_{3}\right), 2.45\left(\mathrm{~m}, 2 \mathrm{H}, \mathrm{H}_{4^{\prime}}\right), 1.50$ (app.dd, $1 \mathrm{H}, J=8.4 \mathrm{~Hz}, \mathrm{H}_{3^{\prime}}$ ), 1.29 (app.dd, $\left.1 \mathrm{H}, J=8.4 \mathrm{~Hz}, \mathrm{H}_{3^{\prime}}\right) .{ }^{13} \mathrm{C} \mathrm{NMR}$ $\left(\mathrm{CDCl}_{3}, 75 \mathrm{MHz}, \delta\right): 172.8\left(\mathrm{C}_{1}\right), 147.1\left(\mathrm{C}_{6}\right), 135.5\left(\mathrm{C}_{1^{\prime}}\right), 133.2$ $\left(\mathrm{C}_{7}\right), 131.7\left(\mathrm{C}_{4}\right), 105.0\left(\mathrm{C}_{5}\right), 64.7\left(\mathrm{C}_{5^{\prime}}\right), 56.4\left(\mathrm{C}_{8}\right), 49.0\left(\mathrm{C}_{3^{\prime}}\right), 45.5$ $\left(\mathrm{C}_{2^{\prime}}\right), 40.7\left(\mathrm{C}_{4^{\prime}}\right), 36.4\left(\mathrm{C}_{2}\right), 31.3\left(\mathrm{C}_{3}\right)$. FT-IR (neat): $\nu_{\max } 3516$ $(\mathrm{ArOH}), 1732(\mathrm{C}=\mathrm{O}), 1608-1451\left(\mathrm{C}=\mathrm{C}_{\mathrm{Ar}}\right)$. UV (nm): $\lambda_{\max }: 205$. HRMS (TOF MS, ES+): $m / z$ calcd for $\mathrm{C}_{31} \mathrm{H}_{38} \mathrm{O}_{10} \mathrm{Na}$ : 593.2363; found: 593.2371

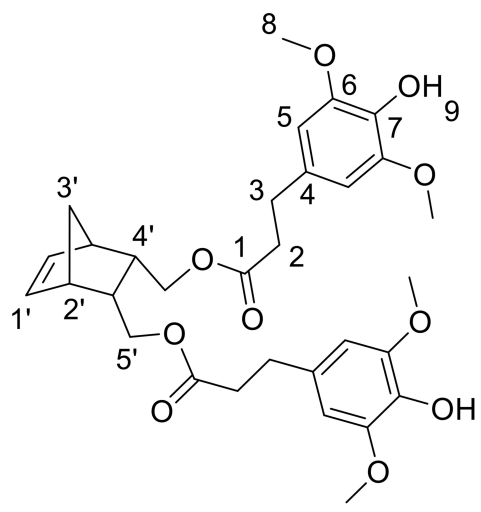




\section{General Polymerization Procedure [poly(NDF) and poly(NDS)]}

In a typical experiment, a $25 \mathrm{~mL}$ flask is charged with monomer (NDF) or (NDS) (500 mg) under $\mathrm{N}_{2} . \mathrm{CH}_{2} \mathrm{Cl}_{2}$ (so that the final volume of the solution is $7.15 \mathrm{~mL}$ ) and Grubbs $1^{\text {st }}$ generation or Hoveyda-Grubbs $2^{\text {nd }}$ generation catalyst solution in dichloromethane $(8 \mathrm{mmol} / \mathrm{L})$, were added with a syringe in sequence at different monomer to catalyst molar ratio ([M]/[C]) (from 25 to 1000). The mixture was stirred at room temperature for $3 \mathrm{~h}$ under $\mathrm{N}_{2}$. Ethyl vinyl ether $(1 \mathrm{~mL})$ was added to the mixture to quench the reaction and stirred for additional $10 \mathrm{~min}$. The resulting polymer (poly(NDF) or poly(NDS)) was precipitated with an excess of diethyl ether at $0{ }^{\circ} \mathrm{C}$. The polymer was filtered and washed with diethyl ether. A solid is obtained.

\section{General Co-polymerization Procedure [poly(N-co-NDF) and poly(N-co-NDS)]}

In a typical experiment, a $25 \mathrm{~mL}$ flask is charged with monomers (NDF) or (NDS) and norbornene (N) $(500 \mathrm{mg}$, molar ratio $[\mathbf{N}] /[\mathrm{NDX}]$ from 0.33 to 9) under $\mathrm{N}_{2} \cdot \mathrm{CH}_{2} \mathrm{Cl}_{2}$ (so that the final volume of the solution is $6 \mathrm{~mL}$ ) and Grubbs 1st generation catalyst solution in dichloromethane $(8 \mathrm{mmol} / \mathrm{L}, 2 \mathrm{~mol} \%)$ were added with a syringe in sequence (total volume of solvent was $6 \mathrm{~mL})$. Ethyl vinyl ether $(1 \mathrm{~mL})$ was added to the mixture to quench the reaction and stirred for additional $10 \mathrm{~min}$. The resulting polymer [poly(N-co-NDF) or poly(N-co-NDS)] was precipitated with an excess of diethyl ether at $0{ }^{\circ} \mathrm{C}$. The polymer was filtered and washed with diethyl ether. A solid is obtained.

\section{General Hydrogenation Procedure}

The polymer is charged with $p$-toluenesulfonyl hydrazine (5 eq per double bond calculated) into a round-bottom flask. $10 \mathrm{~mL}$ of xylene are added with MOPS buffer $(40 \mathrm{mg} / \mathrm{mL})$. The reaction is heated at $135^{\circ} \mathrm{C}$. After $4 \mathrm{~h}$, the reaction medium is allowed to cool down and then is filtered (Hahn, 1992). The polymer is precipitated into diethyl ether. Powders are obtained.

\section{DPPH Analyses}

Hundred and ninety microliter of homogeneous DPPH solution $(200 \mu \mathrm{M})$ in ethanol are added to a well containing $10 \mu \mathrm{L}$ of potential antiradical molecule solution in ethanol at different concentrations (from $300 \mu \mathrm{M}$ to $9.3 \mu \mathrm{M}$ ). The reaction is followed by a microplate Multiskan FC, 1 scan every 5 min for $7.5 \mathrm{~h}$ at $515 \mathrm{~nm}$. The use of different amounts of potential antioxidant give the $\mathrm{EC}_{50}$ value, which is describe as the efficient concentration needed to reduce half the initial population of DPPH. Each analysis was performed 4 times to have a mean value.

\section{Radical Scavenging Ability (RSA)}

$0.004 \mathrm{mmol}$ of polymer are solubilized in $0.5 \mathrm{~mL}$ of chloroform. $0.1 \mathrm{~mL}$ of the polymer solution are dropped off in a quartz cell. Then the cell is placed under $\mathrm{N}_{2}$ for $1 \mathrm{~h}$. We obtained a polymer film on the bottom of the cell. Two milliliters of a DPPH solution $(0.1 \mathrm{mM})$ are added in the cell and the absorbance at $515 \mathrm{~nm}$ is measured at $t=0$ and $t=3 \mathrm{~h}$.

\section{RESULTS AND DISCUSSION}

\section{Chemo-Enzymatic Synthesis of Monomers}

The two norbornene-derived ester monomers bearing SHP groups, NDF and NDS, were prepared as described in Scheme 1. The first step consisted in synthesizing ethyl dihydroferulate (1, 98\%) and ethyl dihydrosinapate (2, 92\%) from ferulic acid and sinapic acid, respectively, through a two-step one-pot route involving Fisher esterification and palladium-mediated hydrogenation. 5-Norbornene-2endo,3endo-dimethanol (3) was then synthesized through the reduction of 5-norbornene2,3-dicarboxylic anhydride in presence of $\mathrm{LiAlH}_{4}$ (94\% yield). Finally, the solvent-free CAL-B-mediated transesterification<smiles>[R]c1cc(/C=C/C(=O)O)cc(OC)c1O</smiles>

Ferulic acid: $\mathrm{R}=\mathrm{H}$ Sinapic acid: $\mathrm{R}=\mathrm{OMe}$<smiles>O=C1OC(=O)C2C3C=CC(C3)C12</smiles>

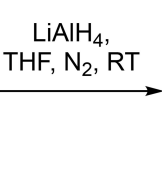

1) $\mathrm{HCl}_{\text {cat }}, \mathrm{EtOH}, 100^{\circ} \mathrm{C}$ 2) $\mathrm{Pd} / \mathrm{C}, \mathrm{H}_{2}$, EtOH, RT<smiles>[R]c1cc(CCC(=O)OCC)cc(OC)c1O</smiles>

(1): $\mathrm{R}=\mathrm{H}, 98 \%$

(2): $\mathrm{R}=\mathrm{OMe}, 92 \%$<smiles>OCC1C2C=CC(C2)C1CO</smiles>

(3), $94 \%$<smiles>[R]c1cc(CCC(=O)OCC2C3C=CC(C3)C2COC(=O)CCc2cc([R])c(O)c(OC)c2)cc(OC)c1O</smiles>

NDF: $\mathrm{R}=\mathrm{H}, 87 \%$

NDS: $\mathrm{R}=\mathrm{OMe}, 60 \%$

SCHEME 1 | Chemo-enzymatic synthesis of NDF and NDS monomers. 
(Pion et al., 2013) of $\mathbf{1}$ and $\mathbf{2}$ by $\mathbf{3}$ was performed to provide NDS (60\%) and NDF (80\%) monomers, respectively. One of the main advantages of using CAL-B in this synthesis is its inactivity toward phenols. Indeed, this particular selectivity renders unnecessary atom- and solvent-consuming protection/deprotection sequence. In addition, this bio-catalysis can be conducted under mild conditions $\left(70{ }^{\circ} \mathrm{C}\right.$, solvent-free, under reduced pressure) and CAL-B can be readily recovered by filtration at the end of reaction. Finally, compared to the chemical synthesis of the similar monomer reported by Xue et al. (2007), this biocatalytic process is not only greener but also provides higher yields (60-80 vs. 37\% (Xue et al., 2007)).

The monitoring of ethyl dihydroferulate (1) transesterification with 3 using ${ }^{1} \mathrm{H}$ NMR spectroscopy showed that it takes about 3 days to reach high yields, providing NDF in $87 \%$ yield after flash chromatography. In the case of NDS, for the same reaction time, a very low reactivity of ethyl dihydrosinapate (2) toward the enzyme was observed as NDS was obtained in 10\% yield while up to $60 \%$ of norbornene mono-sinapate (NMS) was produced (Figure 2). It was shown that the reaction had to be run for more than 10 days to reach a NDS yield of $60 \%$.

Both compounds were tested for their antiradical activity by using the DPPH method that determines the H-donor capacity of the antioxidant to quench the stable DPPH free radical, as previously reported (Reano et al., 2015). In this study, $\mathrm{EC}_{50}$ value corresponds to the amount of antioxidant (nmol) needed to reduce half of the initial population of DPPH radicals. The lower the $\mathrm{EC}_{50}$ value, the higher the antiradical activity. The total stoichiometry $n_{\text {tot }}$ (number of DPPH molecules reduced by one molecule of antioxidant) of the monomers were also expressed in Table 1, according to: $n_{\text {tot }}=n_{\mathrm{DPPH}} / 2^{*} \mathrm{EC}_{50}\left[n_{\mathrm{DPPH}}\right.$ : initial DPPH mole number (nmol)].

As expected, data in Table $\mathbf{1}$ confirm the significant positive impact of methoxy group on both radical stability $(+M$, mesomeric effect) and antiradical activity since the higher the degree of methoxylation (NDF (1) vs. (NDS (2)), the lower the $\mathrm{EC}_{50}\left(\mathrm{NDF}\left(\mathrm{EC}_{50}=3.43 \mathrm{nmol}\right)\right.$ vs. NDS $\left(\mathrm{EC}_{50}=2.29\right.$ nmol)). NDS also exhibits a slightly higher antiradical activity than Iganox $1010^{\circledR}$. It is also noteworthy to mention that antiradical activity reported by the phenol numbers for NDF and NDS (i.e., 2 phenols for NDF and NDS and 4 phenols for

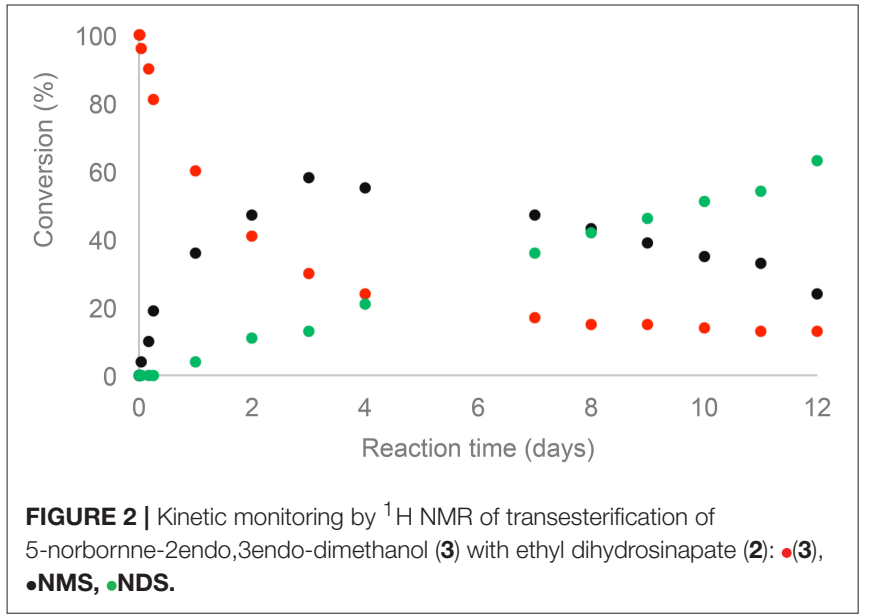

Irganox $\left.1010^{\circledR}\right)$ are significantly higher than that of commercial $\operatorname{Irganox} 1010^{\circledR}$.

\section{ROMP (Co-)Polymerizations and Characterization of the Resulting (Co-)Polymers \\ Homo-Polymerization of NDF and NDS}

The ROMP homopolymerization of NDF and NDS antioxidant monomers $([\mathrm{M}])$ was performed using Grubs $1^{\text {st }}$ generation (GI), and Hoveyda-Grubbs $2^{\text {nd }}$ generation (HGII) catalysts ([C]) at various catalyst $[\mathrm{M}] /[\mathrm{C}]$ molar ratios ranging from 25 to 1000. Because of the high reactivity of norbornene derivative in ROMP, room temperature was chosen to perform polymerization reactions while preventing insoluble high molecular weight polymers. Dichloromethane was used as solvent in invariable reaction medium volume of $7.15 \mathrm{~mL}$ under a low and steady nitrogen flow. All ROMP reactions were run for $3 \mathrm{~h}$ and followed by GPC in order to identify the best conditions (monomers nature, GI vs. HGII, $[\mathrm{M}] /[\mathrm{C}])$. The number molecular weight $\left(M_{n}\right)$ of polymers, degree of polymerization $\left(D P_{n}\right)$, and polydispersity index (PDI) are summarized in Table 2.

TABLE 1 | Antiradical activity of NDF and NDS.

\begin{tabular}{lcccc}
\hline Entry & Monomer & EC $_{\mathbf{5 0}}(\mathbf{n m o l})$ & $\boldsymbol{n}_{\text {tot }}$ & $\boldsymbol{n}_{\text {tot }} /$ phenol \\
\hline 1 & NDF & $3.43 \pm 0.05$ & $5.5 \pm 0.08$ & $2.9 \pm 0.04$ \\
2 & NDS & $2.29 \pm 0.18$ & $8.3 \pm 0.65$ & $4.4 \pm 0.32$ \\
3 & Irganox $1010^{\circledR}$ & $2.75 \pm 0.28$ & $6.9 \pm 0.70$ & $1.8 \pm 0.18$ \\
\hline
\end{tabular}

TABLE 2 | GPC and DSC data of synthesized polymers via ROMP.

\begin{tabular}{|c|c|c|c|c|c|c|c|}
\hline Entry & Monomer & Catalyst & {$[\mathrm{M}] /[\mathrm{C}]$} & $M_{n}(\mathrm{kDa})$ & ${ }^{\mathrm{a}} D P_{n}$ & aPDI & ${ }^{\mathrm{b}} T_{g}\left({ }^{\circ} \mathrm{C}\right)$ \\
\hline 1 & NDF & $\mathrm{Gl}$ & 25 & 7.2 & 14 & 2.0 & 32 \\
\hline 2 & NDF & $\mathrm{Gl}$ & 50 & 14.3 & 28 & 2.0 & 33 \\
\hline 3 & NDF & $\mathrm{Gl}$ & 200 & 22.0 & 43 & 2.5 & 36 \\
\hline 4 & NDF & $\mathrm{Gl}$ & 500 & 20.7 & 41 & 2.3 & 37 \\
\hline 5 & NDF & $\mathrm{Gl}$ & 1000 & 20.5 & 40 & 2.3 & 31 \\
\hline 6 & NDF & HGII & 25 & Insoluble & - & - & - \\
\hline 7 & NDF & HGII & 50 & Insoluble & - & - & - \\
\hline 8 & NDF & HGII & 200 & Insoluble & - & - & - \\
\hline 9 & NDF & HGII & 500 & Insoluble & - & - & - \\
\hline 10 & NDF & HGII & 1000 & Insoluble & - & - & - \\
\hline 11 & NDS & $\mathrm{Gl}$ & 25 & 3.6 & 7 & 2.1 & 48 \\
\hline 12 & NDS & $\mathrm{Gl}$ & 50 & 4.5 & 8 & 1.8 & 54 \\
\hline 13 & NDS & $\mathrm{Gl}$ & 200 & 14.1 & 25 & 2.2 & 55 \\
\hline 14 & NDS & $\mathrm{Gl}$ & 500 & 15.0 & 26 & 2.0 & 54 \\
\hline 15 & NDS & $\mathrm{Gl}$ & 1000 & 20.5 & 40 & 2.1 & 56 \\
\hline 16 & NDS & HGII & 25 & Insoluble & - & - & - \\
\hline 17 & NDS & HGII & 50 & Insoluble & - & - & - \\
\hline 18 & NDS & HGII & 200 & Insoluble & - & - & - \\
\hline 19 & NDS & HGII & 500 & Insoluble & - & - & - \\
\hline 20 & NDS & HGII & 1000 & Insoluble & - & - & - \\
\hline
\end{tabular}

Polymerization conditions: 3 h at room temperature. ${ }^{a}$ GPC analyses: PLGel MixedD, $40^{\circ} \mathrm{C}$ THF, $1 \mathrm{~mL} \mathrm{~min}{ }^{-1}$, UV $280 \mathrm{~nm}, \mathrm{Rl}$, calibration with polystyrene standards. ${ }^{b} \mathrm{DSC}$ data recording at $10{ }^{\circ} \mathrm{C} \mathrm{min}-1$ under nitrogen $\left(60 \mathrm{~mL} \mathrm{~min}^{-1}\right)$, value determined at the $2 \mathrm{nd}$ heating scan. 

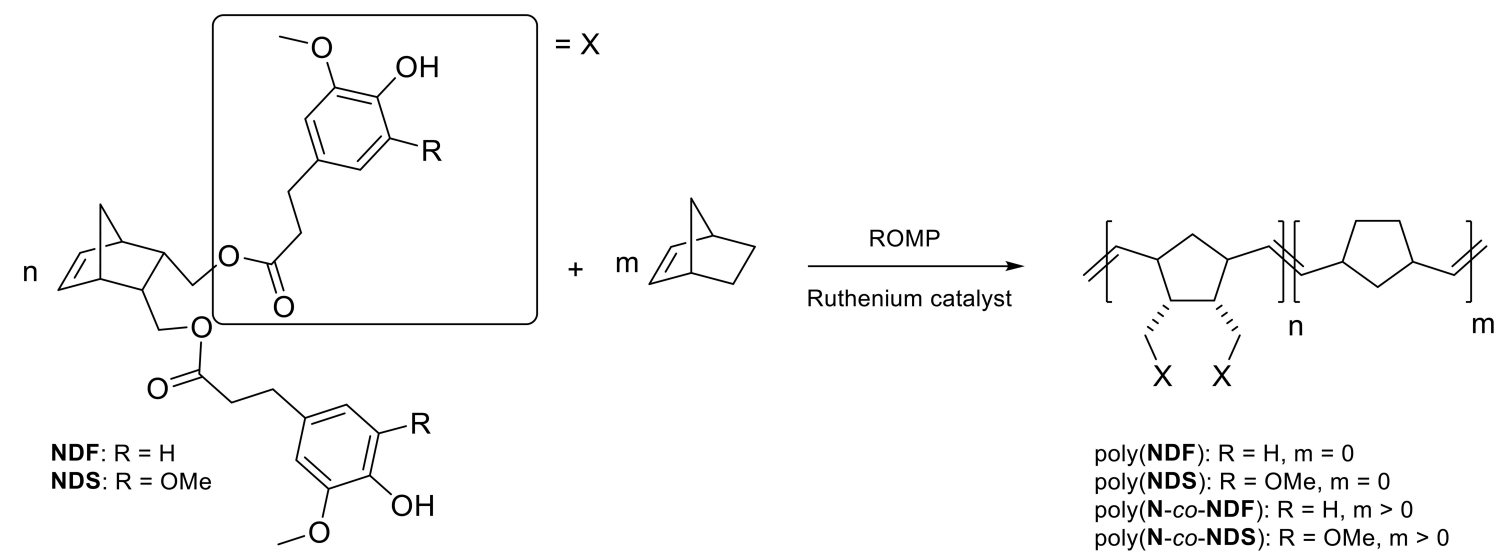

poly(NDF): $\mathrm{R}=\mathrm{H}, \mathrm{m}=0$

poly(NDS): $R=$ OMe, $m=0$

poly(N-co-NDF): $\mathrm{R}=\mathrm{H}, \mathrm{m}>0$

poly(N-co-NDS $): R=O M e, m>0$

SCHEME 2 | NDF or NDS (co-)polymerization via ROMP.

TABLE 3 | GPC characterization of crude copolymer via ROMP.

\begin{tabular}{|c|c|c|c|c|c|}
\hline Entry & Monomer & {$[\mathrm{N}] /[\mathrm{NDX}]_{\text {theo }}$} & {$[N] /[N D X]_{\exp }^{a}$} & ${ }^{b} M_{n}$ (kDa) & ${ }^{\text {b PDI }}$ \\
\hline 1 & N-NDF & $1 / 3$ & Insoluble & 13.8 & 2.1 \\
\hline 2 & N-NDF & 1 & Insoluble & 9.6 & 2.2 \\
\hline 3 & N-NDF & 3 & Insoluble & 7.7 & 3.1 \\
\hline 4 & N-NDF & 9 & n.d. & 7.0 & 5.2 \\
\hline $4^{\star}$ & $\mathbf{N}-N^{*} F^{*}$ & 9 & $11.5^{\star}$ & $15.8^{*}$ & $2.9^{*}$ \\
\hline 5 & N-NDS & $1 / 3$ & Insoluble & 14.9 & 3.1 \\
\hline 6 & N-NDS & 1 & Insoluble & 11.8 & 3.8 \\
\hline 7 & N-NDS & 3 & Insoluble & 8.4 & 5.7 \\
\hline 8 & N-NDS & 9 & n.d. & 7.3 & 5.9 \\
\hline $8^{\star}$ & N-NDS* & 9 & $10.1^{*}$ & $25.2^{*}$ & $2.6^{\star}$ \\
\hline
\end{tabular}

Polymerization conditions: $\mathrm{Gl}$ (molar ratio $[\mathrm{M}] /[\mathrm{C}]=50$ ), $3 \mathrm{~h}$ at room temperature. ${ }^{a}$ Calculated by $1 \mathrm{H} \mathrm{NMR.}{ }^{b} \mathrm{GPC}$ analyses of crude polymers: PLGel MixedD, $40{ }^{\circ} \mathrm{C} \mathrm{THF}$, $1 \mathrm{~mL} \mathrm{~min}{ }^{-1}$, UV $280 \mathrm{~nm}, \mathrm{Rl}$, calibration with polystyrene standards. *Data after acetone wash.

Because of high molecular weights, ROMP polymerization performed with HGII catalyst became too viscous to be efficiently stirred after $15 \mathrm{~min}$ independently of $[\mathrm{M}] /[\mathrm{C}]$ ratios (Table 2, entries 6-10 and 16-20). Resulting polymers could not be dissolved thus preventing any characterization by GPC.

On the basis of the results reported in Table 2, and as expected, a correlation between $M_{n}$ and catalyst loading with GI polymerization was found (Table 2, entries 1-5 and 10-15). Indeed, $M_{n}$ increases with the increase of $[\mathrm{M}] /[\mathrm{C}]$ ratio under the same reaction conditions for both NDF $\left(M_{n}\right.$ entries $1<$ $2<3$ ) and NDS $\left(M_{n}\right.$ entries $\left.11<12<13\right)$. ROMP being a chain growth type polymerization, the amount of reactive initiative species in chain initiation step increases with catalyst loading. Consequently, decreasing catalyst loading shifts the polymerization toward chain propagation and thus leads to higher molecular weight. In the case of NDF, an interesting plateau effect around $20.0 \mathrm{kDa}$ values was observed from $[\mathrm{M}] /[\mathrm{C}]$ $=200$. Corresponding polymerization at higher ratios (i.e., 500 and 1000) resulted in $M_{n}$ not exceeding $22.0 \mathrm{kDa}$. It is noteworthy to mention that a $[\mathrm{M}] /[\mathrm{C}]$ ratio of 1,000 is needed to reach this $M_{n}$ value with NDS. Finally, PDI values were in the range of 1.82.5 , demonstrating a good homogeneity of the polymers chain length.

The thermal properties of the resulting polymers were investigated by thermogravimetric analysis (TGA) and differential scanning calorimetry (DSC) (see Table 2 and Electronic Supporting Information). TGA analyses of poly(NDF) and poly(NDS) revealed thermal stability $\left(T_{d 50 \%}\right)$ higher than $350{ }^{\circ} \mathrm{C}$ in agreement with literature data on functionalized polynorbornene (Liu et al., 2007). No correlation was observed between thermal stability $\left(T_{d 50 \%}\right)$ and degree of polymerization $\left(D P_{n}\right)$. DSC analyzes showed a $20{ }^{\circ} \mathrm{C}$ difference in $T_{g}$ values between poly(NDF) and poly(NDS). Such difference is certainly due to the presence of an extra methoxy group on the aromatic ring in NDS that induces more rigidity to the monomer as previously reported (Janvier et al., 2017). Finally, it is noteworthy to mention that all polymers are amorphous and do not exhibit melting points $\left(T_{m}\right)$ on DSC.

\section{Co-polymerization of Norbornene (N) with NDF or NDS}

As the antioxidant activity is directly linked to the number of phenolic moieties, one could easily tune the antioxidant activity of the polymers by adjusting the number of SHP groups present per weight unit. Under these considerations, co-polymerization between antioxidant functionalized monomer (NDF or NDS) and non-active norbornene (N) has been performed (Scheme 2). Previous polymerization conditions were applied with molar ratio $[\mathbf{N}] /[\mathbf{N D X}]$ varying from $1 / 3$ to 9 . Table 3 summarizes analytical data from GPC analyses.

Increasing norbornene content during copolymerization strongly impacted the solubility of the resulting copolymers. Only a $[\mathbf{N}] /[\mathbf{N D X}]$ ratio of 9 (Table 3 , entries 4 and 8) provided soluble polymers after removing the catalyst by precipitation in diethyl ether. Therefore, GPC analyses were carried out directly on crude reaction medium before precipitation to measure $M_{n}$ and PDI values. These results showed distinctly that the decrease 


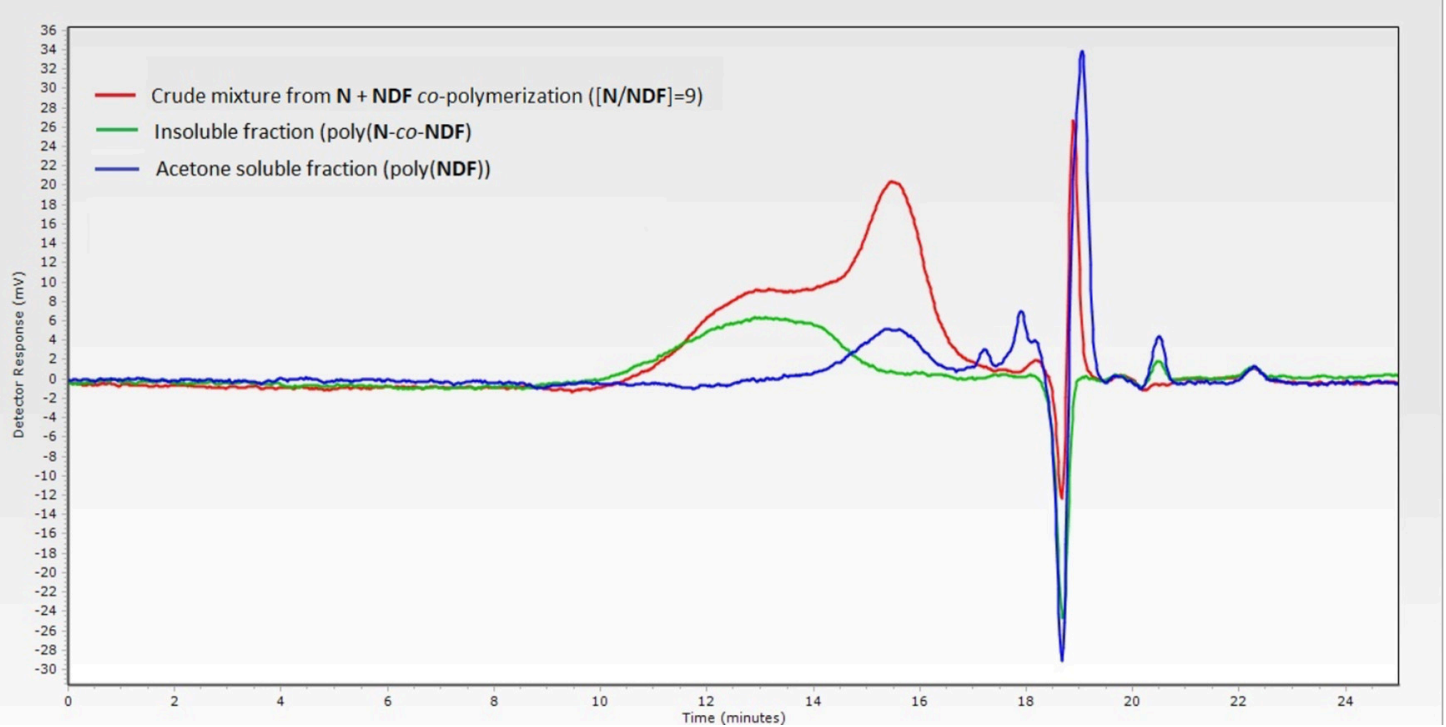

FIGURE 3 | GPC traces of crude copolymerization (red), acetone-soluble polymers (blue) and acetone-insoluble polymers (green).

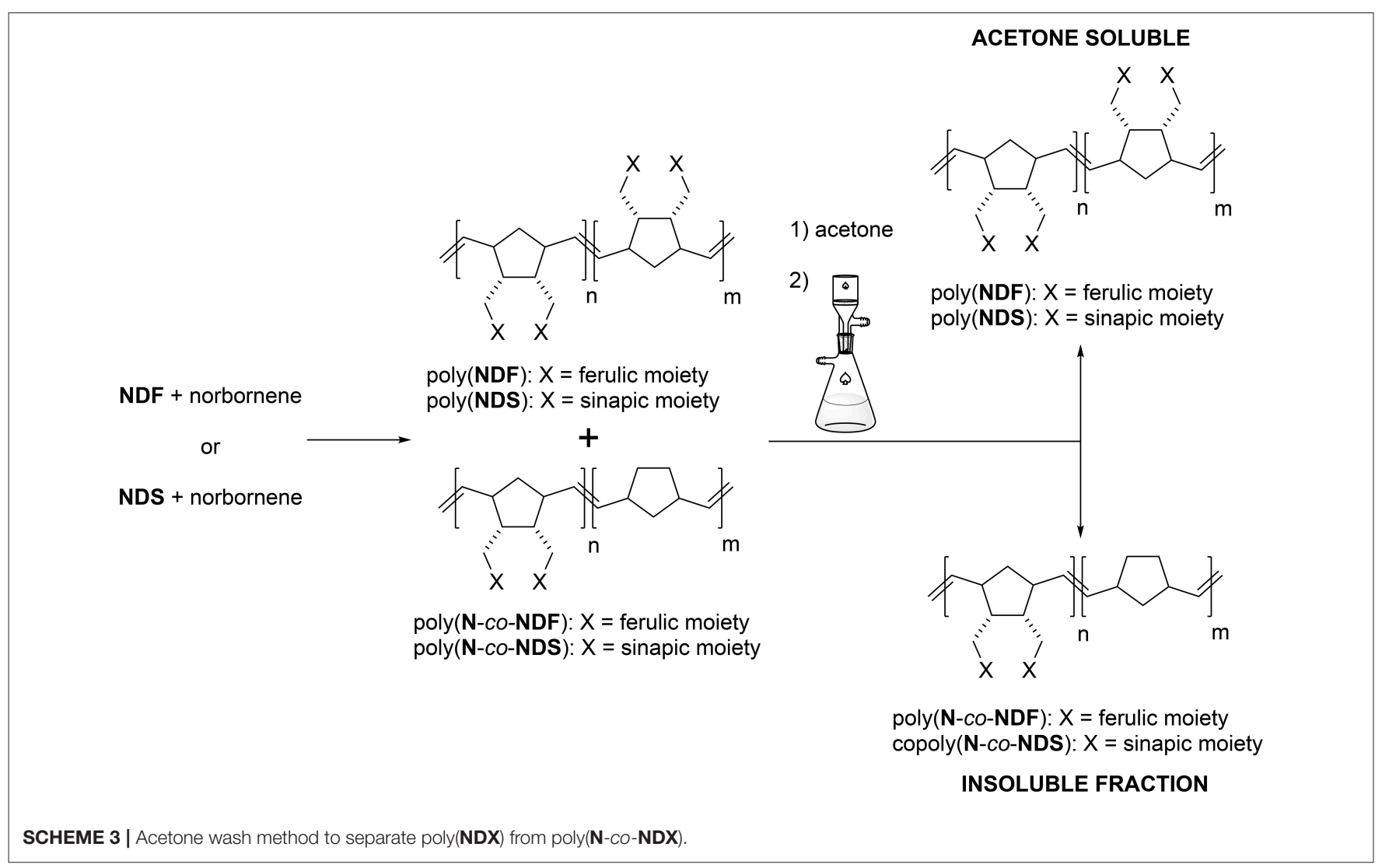

of NDF/NDS monomer content results in decreasing $M_{n}$ values down to $7.0 \mathrm{kDa}$, while PDI value skyrockets over 5.0 (Table 3, entry 1 vs. entry 4). GPC trace investigation reveals a bimodal distribution explaining the significant increase of PDI values while inducing irremediably inaccurate $M_{n}$ estimations (Figure 3 - red trace). Judging from this observation, it was concluded that co-polymerization probably gave two different species of polymers. 
Advantageously, we found out that a simple acetone wash allowed the separation of the two types of polymers (Scheme 3), which were then analyzed separately by GPC, revealing more acceptable $M_{n}$ and PDI values (Figure 3-green trace, Table 3 - entries $4^{*}$ and $8^{*}$, Table 4$)$. By combining GPC traces (Figure 3-blue trace) and ${ }^{1} \mathrm{H}$ NMR spectroscopy data (see ESI), it was established that the soluble polymers present in the acetone fraction correspond to homo-polymers poly(NDF) or poly(NDS), while the insoluble polymer was a copolymer of norbornene (N) and NDF or NDS, poly(N-co-NDF) and poly(N-co-NDS), respectively.

\section{Hydrogenation}

The unsaturated polymers obtained by ROMP being susceptible to oxidation and less thermally stable than their saturated counterparts (Linwood et al., 1989; Yoon et al., 2012) poly(NDF), poly(NDS), poly(N-co-NDF) and poly(N-co-NDS) have been submitted to hydrogenation in presence of $p$ toluenesulfonylhydrazine ( $p$-TSH) as described by Xue et al. (2008) (Scheme 4). An excess of $p$-TSH (5 eq. per double bound) was used as a precursor to generate diimide and $p$-TSH in situ (a). The generated diimide reduced selectively apolar double bound, leaving the aromatic rings of the SHP untouched, and gave off $\mathrm{N}_{2}$ gas (b).

It is noteworthy to mention that the co-generated $p$-TSH can lead to chemical degradation of polymers, thus resulting

TABLE 4 | GPC characterization of (co-)polymers after acetone wash.

\begin{tabular}{|c|c|c|c|c|c|c|}
\hline Entry & Monomers & $\begin{array}{c}{[\mathrm{N}] /} \\
{[\mathrm{NDX}]_{\text {theo }}}\end{array}$ & Polymers & $\begin{array}{c}{[N] /} \\
{[N D X]_{\exp }^{a}}\end{array}$ & ${ }^{b} M_{n}$ (kDa) & ${ }^{\text {b}}$ PDI \\
\hline \multirow[t]{2}{*}{1} & $\mathbf{N}+\mathbf{N D F}$ & 9 & Poly(N-co-NDF) & 11.5 & 15.8 & 2.9 \\
\hline & & & Poly(NDF) & - & 6.5 & 1.8 \\
\hline \multirow[t]{2}{*}{2} & $\mathbf{N}+\mathbf{N D S}$ & 9 & Poly(N-co-NDS) & 10.1 & 25.2 & 2.6 \\
\hline & & & Poly(NDS) & - & 2.6 & 1.4 \\
\hline
\end{tabular}

Polymerization conditions: Gl (molar ratio $[\mathrm{M}] /[\mathrm{C}]=50), \mathrm{DCM}(6 \mathrm{~mL}), 3 \mathrm{~h}$ at room temperature. ${ }^{a}$ Calculated by 1 H NMR. ${ }^{b}$ GPC analyses of crude polymers: PLGel MixedD, $40{ }^{\circ} \mathrm{C} \mathrm{THF,} 1 \mathrm{~mL} \mathrm{~min}^{-1}$, UV $280 \mathrm{~nm}, \mathrm{Rl}$, calibration with polystyrene standards.

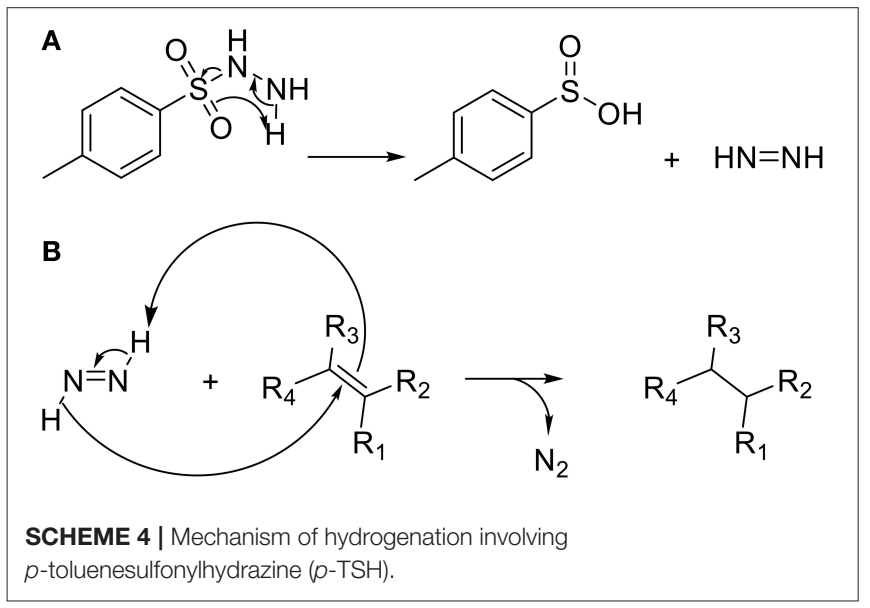

in a decrease of $M_{n}$ (Yoon et al., 2011). Therefore, basic reagents such as MOPs were used to neutralize $p$-toluenesulfinic acid (Table 5). Under these conditions, all unsaturations were successfully removed as evidenced by the absence of the olefinic peaks at 5.0-5.7 ppm in the ${ }^{1} \mathrm{H}$ NRM spectrum of the resulting polymers (Figure 4). Unfortunately, all our attempts to develop a greener hydrogenation procedure remained unsuccessful.

\section{Antiradical Activity Determination Using DPPH Analysis}

In DPPH analysis, radical scavenging ability (\%RSA) is linked to the ability of SHP molecules to scavenge $\alpha, \alpha$-diphenyl- $\beta$ picrylhydrazyl (DPPH) free radical (Blois, 1958; Brand-Williams et al., 1995). In this study, \%RSA was defined as the rate of absorption loss for DPPH solution measured at $515 \mathrm{~nm}$ after shaking for $3 \mathrm{~h}$ in presence of equimolar amount of poly- $\mathrm{H}$ (NDF), poly-H-(NDS), poly-H-(N-co-NDF) or poly-H-(N-coNDS) copolymers films. Only copolymers with $[\mathbf{N}] /[\mathbf{N D X}]$ ratio of 9 were submitted to the RSA test as the others copolymers were poorly soluble.

Table 6 shown RSA $<2 \%$ for polynorbornene. Bearing no SHP group, this very low activity was due only to auto-reduction of DPPH in solution during analysis time $(3 \mathrm{~h})$. Homopolymers poly-H-(NDF) and poly-H-(NDS) exhibited interesting activities as both reduced more than $80 \%$ of the initial population of free radical. In addition, as already observed at the monomer level, poly-H-(NDS) is more antioxidant than poly-H-(NDF). Logically, due to a lower SHP content, the RSA of copolymers poly-H-(N-co-NDF) and poly-H-(N-co-NDS) is lower than that of poly-H-(NDF) and poly-H-(NDS), respectively. However, it is noteworthy to mention that a 9-fold decrease of SHP content (poly-H-(N-co-NDF) vs. poly-H-(NDF), poly-H-(N-co-NDS) vs. poly-H-(NDS)) only resulted in a ca. 2-fold decrease in RSA, demonstrating that not only the radical scavenging activity is not proportional to the SHP content, but also that only a relatively small SHP content is needed to provide a potent antioxidant activity to the polymers.

\section{CONCLUSIONS}

Biobased antioxidant monomers bearing SHP were successfully synthesized from renewable ferulic and sinapic acids using a sustainable process involving a lipase-mediated

TABLE 5 | GPC characterization of hydrogenate polymer.

\begin{tabular}{llcc}
\hline Entry & Polymer & {$[\mathbf{N}] /[\mathbf{N D X}]_{\text {theo }}$} & $\boldsymbol{a}_{\boldsymbol{M}_{\boldsymbol{n}} \text { (kDa) }}$ \\
\hline 1 & poly-H-(NDF) & - & 18.5 \\
2 & poly-H-(NDS) & - & 13.5 \\
3 & poly-H-(N-co-NDF) & 9 & 12.0 \\
4 & poly-H-(N-CO-NDS) & 9 & 19.0 \\
\hline
\end{tabular}

${ }^{a}$ GPC analyses of crude polymers: PLGel MixedD, $40{ }^{\circ} \mathrm{C}$ THF, $1 \mathrm{~mL} \mathrm{~min}{ }^{-1}$, UV $280 \mathrm{~nm}$, $R$, calibration with polystyrene standards. 


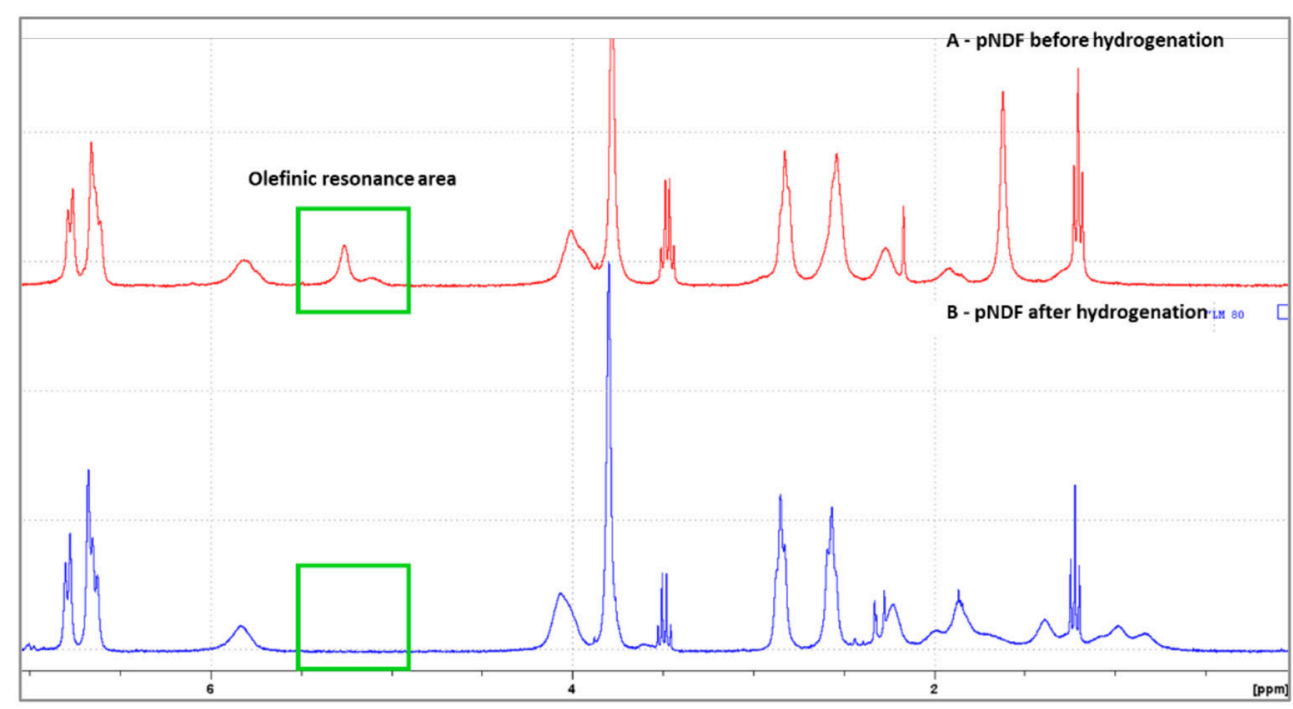

FIGURE $4 \mid{ }^{1}$ H NMR spectra (300 MHz) of poly(NDF) before (A-red) and after hydrogenation (B-blue).

TABLE 6 | Radical scavenging ability of polymers and copolymers.

\begin{tabular}{llcccc}
\hline Entry & Polymer & $\begin{array}{c}{[\mathbf{N}] /} \\
{[\mathbf{N D X}]_{\text {theo }}}\end{array}$ & $\boldsymbol{M}_{\boldsymbol{n}}$ (kDa) & $\%$ RSA & $\%$ RSA/phenol \\
\hline 1 & poly-H-(N) & - & - & $2.0 \pm 0.5$ & - \\
2 & poly-H-(NDF) & - & 18.5 & $82.3 \pm 1.9$ & $1.1 \pm 0.03$ \\
3 & poly-H-(NDS) & - & 13.5 & $91.8 \pm 1.3$ & $1.9 \pm 0.03$ \\
4 & poly-H-(N-co-NDF) & 9 & 12.0 & $40.0 \pm 1.5$ & $2.7 \pm 0.10$ \\
5 & poly-H-(N-Co-NDS) & 9 & 19.0 & $33.8 \pm 0.9$ & $1.4 \pm 0.04$
\end{tabular}

transesterification. These monomers were then (co-)polymerized using ROMP in presence of Grubbs $1^{\text {st }}$ generation catalyst. Thanks to a very simple procedure involving an acetone wash, the homo- and copolymers where easily separated and fully characterized by GPC, ${ }^{1} \mathrm{H}$ NMR, DSC and TGA before being submitted to hydrogenation. The antioxidant activity of the resulting saturated polymers was assessed by $\mathrm{DPPH}$ analysis and revealed a high antioxidant activity for both homo- and copolymers, and this even for copolymers with SHP-bearing monomer contents as low as $8 \%$. This work demonstrates that the combination of biocatalysis and biobased sterically hindered phenolics such as ferulic and sinapic acids offers a greener and more efficient alternative to those already reported

\section{REFERENCES}

Arefjev, D. V., Domnina, N. S., Komarova, E. A., and Bilibin, A. Y. (1999). Sterically hindered phenol-dextran conjugates: synthesis and radical scavenging activity. Eur. Polym. J. 35, 279-284. doi: 10.1016/S0014-3057(98)00128-1

Blois, M. (1958). Antioxidant determinations by the use of a stable free radical. Nature 181, 1199-1200. doi: 10.1038/1811199a0

Brand-Williams, W., Cuvelier, M. E., and Berset, C. (1995). Use of a free radical method to evaluate antioxidant activity. Food Sci. Technol. 28, 25-30. doi: $10.1016 /$ S0023-6438(95)80008-5 in the literature that uses fossil-based SHP and classic chemical synthesis.

\section{AUTHOR CONTRIBUTIONS}

FA: conceived and managed the research. FD-N and LM: performed the chemo-enzymatic reactions and the characterizations; LH, FR: provided the technical guidelines. FA, $\mathrm{LH}$, and FR: reviewed the results and provided the technical guidelines. FA and LH: wrote and drafted the article. FA and SD: reviewed and approved the article.

\section{ACKNOWLEDGMENTS}

The authors are grateful to the Région Grand Est, the Conseil Départemental de la Marne and Grand Reims for their financial support.

\section{SUPPLEMENTARY MATERIAL}

The Supplementary Material for this article can be found online at: https://www.frontiersin.org/articles/10.3389/fchem. 2017.00126/full\#supplementary-material

Campbell, R. E., McAdon, M. H., Nickias, P. N., Patton, J. T., Redwine, O. D., and Timmers, F. J. (2001). United States Patent, 2, $N^{\circ}$ US 6,191,245 B1.

Code of Federal Regulations Title 21 (2013). Food and Drugs. Washington, DC: US Goverment Print Office, 1-806.

Cuvelier, M.-E., Richard, H., and Berset, C. (1992). Comparison of the antioxidative activity of some acid-phenols: structure-activity relationship. Biosci. Biotechnol. Biochem. 56, 324-325. doi: 10.1271/bbb.56.324

Dias, E. L., Nguyen, S. T., and Grubbs, R. H. (1997). Well-defined Ru olefin metathesis catalysts: mechanism and activity. J. Am. Chem. Soc. 119, 3887-3897. doi: 10.1021/ja963136z 
Dopico-García, M. S., López-Vilariñó, J. M., and Gonzalez-Rodríguez, M. V. (2007). Antioxidant content of and migration from commercial polyethylene, polypropylene, and polyvinyl chloride packages. J. Agric. Food Chem. 55, 3225-3231. doi: 10.1021/jf070102+

Dupoiron, S., Lameloise, M.-L., Pommet, M., Bennaceur, O., Lewandowski, R., Allais, F., et al. (2017). A novel and integrative process: from enzymatic fractionation of wheat bran with a hemicellulasic cocktail to the recovery of ferulic acid by weak anion exchange resin. Ind. Crops Prod. 105, 148-155. doi: 10.1016/j.indcrop.2017.05.004

Girois, S. (2013). Stabilisation des Plastiques Principes Généraux. Tech. l'Ingénieur AM3232. Available online at: https://www.techniques-ingenieur. fr/base-documentaire/materiaux-th11/adjuvants-des-plastiques-42138210/ stabilisation-des-plastiques-am3232/

Hahn, S. F. (1992). An improved method for the diimide hydrogenation of butadiene and isoprene containing polymers. J. Polym. Sci. Part A Polym. Chem. 30, 397-408. doi: 10.1002/pola.1992.080300307

Janvier, M., Hollande, L., Jaufurally, A. S., Pernes, M., Ménard, R., et al. (2017). Syringaresinol: a renewable and safer alternative to bisphenol A for epoxy-amine resins. ChemSusChem. 10, 738-746. doi: 10.1002/cssc.2016 01595

Jaufurally, A. S., Teixeira, A. R. S., Hollande, L., Allais, F., and Ducrot, P.-H. (2016). Optimization of the laccase-catalyzed synthesis of $( \pm)$-syringaresinol and study of its thermal and antiradical activities. Chem. Select 1, 5165-5171. doi: $10.1002 /$ slct.201600543

Kasza, G., Mosnáčkov,á, K., Nádor, A., Osváth, Z., Stumphauser, T., Szarka, G., et al. (2015). Synthesis of hyperbranched poly(ethyleneimine) based macromolecular antioxidants and investigation of their efficiency in stabilization of polyolefins. Eur. Polym. J. 68, 609-617. doi: 10.1016/j.eurpolymj.2015.03.037

Kim, T. H., and Oh, D. R. (2004). Melt grafting of maleimides having hindered phenol antioxidant onto low molecular weight polyethylene. Polym. Degrad. Stab. 84, 499-503. doi: 10.1016/j.polymdegradstab.2004. 01.008

Linwood, P. T., Lane, P. C., and Stricharczuk, P. T. (1989). Hydrogenated, RingOpened Polymers of Cycloolefins. EP0303246 (A2). Available online at: https:// worldwide.espacenet.com/publicationDetails/biblio? II=3\&ND=3\&adjacent= true\&locale $=$ en_EP $\& F T=D \&$ date $=19890215 \& \mathrm{CC}=\mathrm{EP} \& \mathrm{NR}=0303246 \mathrm{~A} 2 \& \mathrm{KC}=$ A2

Liu, B., Lia, Y., Kimb, I. L., Shinc, B.-G., Yoonc, D. Y., and Zhang, L., et al. (2007). Thermal characterization and thermal degradation of poly(norbornene-2,3dicarboxylic acid dialkyl esters) synthesized by vinyl addition polymerization. Polym. Degrad. Stab. 92, 868-875. doi: 10.1016/j.polymdegradstab.2007. 01.029

Marcato, B., Guerra, S., Vianello, M., and Scalia, S. (2003). Migration of antioxidant additives from various polyolefinic plastics into oleaginous vehicles. Int. J. Pharm. 257, 217-225. doi: 10.1016/S0378-5173(03)00143-1

Nguyen, T., and Grubbs, R. H. (1993). Syntheses and activities of new singlecomponent, ruthenium-based olefin metathesis catalysts. J. Am. Chem. Soc. 115, 9858-9859. doi: 10.1021/ja00074a086

Overhage, J., Steinbüchel, A., Priefert, H., and Steinbu, A. (2003). Highly efficient biotransformation of eugenol to ferulic acid and further conversion to vanillin in recombinant strains of Escherichia coli. Appl. Environ. Microbiol. 69, 6569-6576. doi: 10.1128/AEM.69.11.6569-6576.2003
Pion, F., Reano, A. F., Ducrot, P.-H., and Allais, F. (2013). Chemo-enzymatic preparation of new bio-based bis- and trisphenols: new versatile building blocks for polymer chemistry. RSC Adv. 3:8988. doi: 10.1039/c3ra41247d

Pospíšil, J. (1993). Chemical and photochemical behaviour of phenolic antioxidants in polymer stabilization: a state of the art report, part II. Polym. Degrad. Stab. 39, 103-115. doi: 10.1016/0141-3910(93)90130-B

Reano, A. F., Chérubin, J., Peru, A. M. M., Wang, Q., Clément, T., Domenek, S., et al. (2015). Structure-activity relationships and structural design optimization of a series of p-hydroxycinnamic acids-based bis- and trisphenols as novel sustainable antiradical/antioxidant additives. ACS Sustain. Chem. Eng. 3, 3486-3496. doi: 10.1021/acssuschemeng.5b01281

Scherman, O. A., Kim, H. M., and Grubbs, R. H. (2002). Synthesis of welldefined poly ((vinyl alcohol) 2 -alt-methylene) via ring-opening metathesis polymerization. Macromolecules 35, 5366-5371. doi: 10.1021/ma011901a

Schwab, P., Grubbs, R. H., and Ziller, J. W. (1996). Synthesis and applications of RuCl 2 (CHR')(PR 3) 2 : the influence of the alkylidene moiety on metathesis activity. J. Am. Chem. Soc. 118, 100-110. doi: 10.1021/ja952676d

Sousa, F., Guebitz, G. M., and Kokol, V. (2009). Antimicrobial and antioxidant properties of chitosan enzymatically functionalized with flavonoids. Process Biochem. 44, 749-756. doi: 10.1016/j.procbio.2009.03.009

Tilay, A., Bule, M., Kishenkumar, J., and Annapure, U. (2008). Preparation of ferulic acid from agricultural wastes: its improved extraction and purification. J. Agric. Food Chem. 56, 7644-7648. doi: 10.1021/jf801536t

Xue, B., Ogata, K., and Toyota, A. (2007). Synthesis and radical scavenging ability of new polymers from sterically hindered phenol functionalized norbornene monomers via ROMP. Polymer 48, 5005-5015. doi: 10.1016/j.polymer.2007.04.074

Xue, B., Ogata, K., and Toyota, A. (2008). Synthesis of polymeric antioxidants based on ring-opening metathesis polymerization (ROMP) and their antioxidant ability for preventing polypropylene (PP) from thermal oxidation degradation. Polym. Degrad. Stab. 93, 347-352. doi: 10.1016/j.polymdegradstab.2007.12.001

Yoon, K. H., Kim, K. O., Schaefer, M., and Yoon, D. Y. (2012). Synthesis and characterization of hydrogenated poly(norbornene endo-dicarboximide)s prepared by ring opening metathesis polymerization. Polymer 53, 2290-2297. doi: 10.1016/j.polymer.2012.02.047

Yoon, K. H., Park, S. B., Park, I., and Yoon, D. Y. (2011). Synthesis and characterization of novel hydrogenated poly(norbornene bisimide)s prepared from ring opening metathesis polymerization. Bull. Korean Chem. Soc. 32, 3074-3080. doi: 10.5012/bkcs.2011.32.8.3074

Zweifel, H. (1998). Stabilization of polymeric materials. (Springer).

Conflict of Interest Statement: The authors declare that the research was conducted in the absence of any commercial or financial relationships that could be construed as a potential conflict of interest.

Copyright (C) 2017 Diot-Néant, Migeot, Hollande, Reano, Domenek and Allais. This is an open-access article distributed under the terms of the Creative Commons Attribution License (CC BY). The use, distribution or reproduction in other forums is permitted, provided the original author(s) or licensor are credited and that the original publication in this journal is cited, in accordance with accepted academic practice. No use, distribution or reproduction is permitted which does not comply with these terms. 